\title{
Health promotion by nursing technicians from the nurses' perspective
}

\author{
Promoção da saúde por técnicos em enfermagem, na perspectiva de enfermeiros \\ Promoción de la salud por técnicos en enfermería, en la perspectiva de enfermeros
}

Antonia de Fátima Zanchetta Serradilha'

Marli Teresinha Cassamassimo Duarte' ORCID: 0000-0001-9582-2944

Vera Lucia Pamplona Tonete' ORCID: 0000-0002-3620-7519

'Universidade Estadual Paulista Júlio de Mesquita Filho. Botucatu, São Paulo, Brazil.

How to cite this article: Serradilha AFZ, Duarte MTC, Tonete VLP. Health promotion by nursing technicians from the nurses' perspective. Rev Bras Enferm. 2019;72(4):979-87. doi: http://dx.doi.org/10.1590/0034-7167-2018-0552

\section{Corresponding Author:} Antonia de Fátima Zanchetta Serradilha E-mail: antonia.zanchetta@terra.com.br

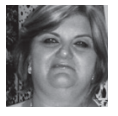

Submission: 07-13-2018 Approval: 09-29-2018

\section{ABSTRACT}

Objective: to analyze education and practice of nursing technicians in health promotion, from the perspective of teaching nurses of technical course and Primary Health Care nurses. Method: an exploratory study with qualitative data analysis, carried out in the city of São Paulo, through semi-structured interviews with nine public technical professors and 16 nurses from the basic health network. Data thematic analysis was carried out. Results: three thematic categories have emerged: Conceptions and experiences on health promotion; Nursing technician's practice in health promotion; and Nursing technician education on health promotion. Final considerations: it is necessary to review the centrality given to technicalism in the education and practice of nursing technicians, contemplating the health promotion and seeking the development of professional competence for the construction of transformative practices aimed at valuing the autonomy and proactivity of the people in health and quality of life production.

Descriptors: Health Promotion; Health Personnel; Nursing; Nursing Education; Primary Health Care.

\section{RESUMO}

Objetivo: analisar a formação e práxis do técnico em enfermagem na promoção da saúde, sob a perspectiva de enfermeiros docentes de curso técnico e da Atenção Primária à Saúde. Método: estudo exploratório com análise qualitativa de dados, realizado em município paulista, por meio de entrevistas semiestruturadas com nove docentes de curso técnico público e 16 enfermeiros da rede básica de saúde. Procedeuse à análise temática dos dados. Resultados: configuraram-se três categorias temáticas: Concepções e experiências sobre promoção da saúde; Práxis do técnico em enfermagem na promoção da saúde; e Formação do técnico em enfermagem para promoção da saúde. Considerações finais: faz-se necessário rever a centralidade dada ao tecnicismo na formação e práxis do técnico em enfermagem, contemplando a promoção da saúde e buscando o desenvolvimento da competência profissional para construção de práticas transformadoras voltadas para valorização da autonomia e proatividade das pessoas na produção de saúde e qualidade de vida.

Descritores: Promoção da Saúde; Pessoal Técnico de Saúde; Enfermagem; Educação em Enfermagem; Atenção Primária à Saúde.

\section{RESUMEN}

Objetivo: analizar la formación y praxis del técnico en Enfermería en la promoción de la salud, bajo la perspectiva de enfermeros docentes de curso técnico y de la Atención Primaria de Salud. Método: estudio exploratorio con análisis cualitativo de datos, realizado en municipio paulista, por medio de entrevistas semiestructuradas con nueve docentes de curso técnico público y 16 enfermeros de la red básica de salud. Se procedió al análisis temático de los datos. Resultados: se configuraron tres categorías temáticas: Concepciones y experiencias sobre promoción de la salud; Práxis del técnico en Enfermería en la promoción de la salud; y Formación del técnico en Enfermería para promoción de la salud. Consideraciones finales: se hace necesario revisar la centralidad dada al tecnicismo en la formación y praxis del técnico en Enfermería, contemplando la promoción de la salud y buscando el desarrollo de la competencia profesional para la construcción de prácticas transformadoras orientadas a la valorización de la autonomía y la proactividad de las personas en la producción de salud y calidad de vida. Descriptores: Promoción de la Salud; Técnicos Medios en Salud; Enfermería; Educación en Enfermería; Atención Primaria de Salud. 


\section{INTRODUCTION}

Primary Health Care (PHC) promotion is one of the fundamental strategies for raising the quality standard of health of individuals and communities.

Health promotion actions aim at promoting the quality of life and reducing the vulnerability linked to the ways of life of the people, showing factors determining and conditioning the health-disease process as: shelter, work, income, education, culture, housing, access, environment and access to goods and services offered to the population. It is understood that in a situation of health vulnerability, individual capacities, social and/or social facilities are restricted in meeting the needs related to the aforementioned determinants and conditioning factors, generating weakening and possibility of achieving certain dangers and threats ${ }^{(1)}$. Thus, in accordance with the Brazilian Unified Health System (SUS - Sistema Único de Saúde) principles and through these actions, it is expected to guarantee the universality, completeness and equity of care ${ }^{(2-3)}$.

Health promotion actions, besides being able to transform the health professionals practice, can also transform users' reality of the services where they work by contributing to the encouragement of their autonomy, with a view to improving their state of health and quality of life ${ }^{(1)}$. Autonomy is the capacity that the human being has in being and doing something independently, without waiting for someone else to do it ${ }^{(3-4)}$.

Health professionals have the role of respecting and encouraging autonomy in their political, social and health dimensions, in a horizontal way, considering people as active and co-participatory subjects in actions to promote health. Themes such as justice and social policies should be part of the education of health professionals, strengthening the development of citizenship and, consequently, health promotion ${ }^{(1)}$.

Nurses, leaders of the nursing teams, are configured as privileged agents that ensure health promotion actions, along with other professionals of these teams, whether in the scope of education or in professional practice. Nursing technicians, due to their potential contribution, are also a major category in the field of health teams, with a large numeric proportion and considerable proximity and bond established with health services users in their daily practice, in order to to contemplate and integrate professional knowledge with those of the attached population ${ }^{(5-6)}$.

In Brazil, nursing technical courses must be organized, based on the Diretrizes Nacionais para a Educação de Nível Técnico (freely translated as Brazilian Guidelines for Education at the Technical Level), instituted by the Brazilian Education Board. These guidelines reinforce the importance of the approach, technical education, integrated actions of protection, prevention, education, recovery and rehabilitation against diseases and grievances, with emphasis on individual and collective needs, including also actions that promote health and that surpass the biomedical-hospital model ${ }^{(7)}$.

Nonetheless, there are still many questions about how and what strategies would be needed to enable students to bring to bear their skills and attitudes in the teaching-learning process, confirming the fundamental role of education institutions and their professors in enabling this process ${ }^{(1)}$.

In education of nurses, there must have a greater appreciation of the traditional teaching model, which is out of context, focused on content and with little or no articulation with health services, undermining the professional's ability to act effectively in health promotion ${ }^{(8)}$. Moreover, in some education institutions, professors are considered as central figures of the teaching-learning process and holders of knowledge. The students' previous experiences and their critical-reflexive and autonomous potentialities are little valued ${ }^{(9)}$.

Since nurses are the ones who most frequently teach in nursing courses, it is inferred that the education of nurses is also not adequate enough to the premises of health promotion, reflecting in their non-effectiveness in professional practice. Practice is the perennial action developed in reality, coupled with constant reflection on it. In the perspective of dialectical materialism, such a "practical-critical" action must ultimately express the transformation of man himself and his historical world ${ }^{(10)}$.

\section{OBJECTIVE}

To analyze education and practice of the nursing technician in health promotion, from the perspective of nurses teaching nursing technical courses and PHC nurses.

\section{METHOD}

\section{Ethical aspects}

The project of this research was sent to the Research Ethics Committee of the Universidade Estadual Paulista Júlio de Mesquita Filho - Faculty of Medicine of Botucatu, recognized by the Brazilian Commission on Ethics in Research of the National Health Board (CONEP, CNS - Comissão Nacional de Ética em Pesquisa do Conselho Nacional de Saúde), being approved, following CNS Resolution $466 / 2012$ that establishes the norms applicable to research that involve the use of data directly obtained with participants ${ }^{(11)}$. Data collection began with presentation of the study and signing of the Free and Informed Consent Form.

\section{Type of study}

This exploratory and qualitative study composes a broader research project that aims to analyze the education and practice of the nursing technician in health promotion from the conceptions and experiences of the subjects involved. Based on the qualitative approach of research, it is possible to express the singularities and meanings of the phenomena for those who experience $i^{(12)}$. In this opportunity, the perspectives of nurses teaching and acting in the $\mathrm{PHC}$ were prioritized, trying to understand the convergences and contradictions that permeate them, in both contexts studied, namely, nursing technical course and basic health network. It should be noted that, for the accomplishment of this study, the 32 items of the checklist in the Consolidated Criteria for Reporting Qualitative Research (COREQ) were followed ${ }^{(13)}$.

\section{Study setting}

This study was carried out in a city in the state of São Paulo, where there is a single public institution that has a nursing technical education course and a PHC network composed of eight 
Basic Health Units (BHU) of a traditional model and 10 Family Health Units (FHU).

\section{Data source}

Nine teaching nurses participated in this study, out of a total of 10 participants in theoretical classes and/or practical courses in public nursing for more than one year. It is noteworthy that a nurse professor refused to participate, claiming unavailability of time.

The health care network of the same municipality, at the time of data collection, had 27 nurses, 14 of whom worked in FHS and 13 in $\mathrm{BHU}$. It is reported that two nurses were on maternity leave. Participants of this nurses group were selected intentionally and gradually in order to reflect, in quantity and intensity, the multiple dimensions of the intended conceptions and experiences ${ }^{(12)}$, making up a total of 16 nurses; eight were working at a BHU and eight at a FHS.

\section{Collection and organization of data}

For the data collection, a semi-structured interview was applied, based on a previously elaborated instrument, which covered aspects related to the sociodemographic, education and work profile of the interviewees and the following questions: For you, what is health promotion? How do you think the teaching of health promotion should be in a nursing technical course? Describe how health promotion has been approached in the context of nursing technician work? How should the nursing technician practice be in promoting health?

The interviews, which had an average duration of 30 minutes, were previously scheduled by telephone contact with the nurses, with the consent of the heads of health units, as well as the direction and pedagogical coordination of the nursing technical course. After the necessary clarifications about the research to participants, the interviews were audio recorded in an MP3 player by one of the authors of this study, nurse, with master's degree in health sciences, doctorate in nursing in progress at the time, professor in nursing technical course, with previous experience in qualitative data collection. Data collection took place from September to December 2016, at the workplace of the interviewees.

The testimonies collected were heard individually by each participant, in a booked room, in their own work environment and, after validation and verbal authorization, were transcribed in full.

\section{Data analysis}

Data were analyzed according to the Thematic Content Analysis technique ${ }^{(14)}$. After the full statements transcription, the authors went through the three stages provided in the aforementioned technique: in the pre-analysis stage, the floating reading of the transcribed statements was carried out, seeking to raise hypotheses about the object under study; in the material exploration stage, the definition of the thematic categories and the identification of the recording units (units of meaning corresponding to the content cut-offs of the statements, considered as base units, aiming at the categorization) and context units in documents (meaning nuclei to encode the record units in order to understand the exact meanings). Finally, in the data treatment and interpretation through intuition, reflexive and critical analysis, the inferential interpretation was performed, especially seeking the latent content in the testimonies ${ }^{(14)}$.

From this analysis process, three thematic categories emerged, each with a variable number of subthemes that are presented in the results, being associated with cuts of some of them, in turn identified by the letter TN (teaching nurse), and letter N (PHC nurse), with the interview order number (1 to 9 ) and (1 to 16) respectively.

\section{RESULTS}

The nine professors of the nursing technical course who participated in the study were female, aged between 33 and 56 years. All had completed undergraduate studies for more than 10 years and had lato sensus postgraduate courses in different areas of health knowledge and a nurse had a master's degree in nursing. These nurses had previous and current experiences of working in Primary Care and hospital care. The period of teaching as a nursing technical school ranged from 12 months to 25 years, with experience in theoretical contents and supervised practice. One of the professors also held the position of coordination of the area, in the nursing technical course.

With respect to the $16 \mathrm{PHC}$ nurses, the age varied between 28 and 56 years and they were female. As for vocational training, all had completed undergraduate nursing between five and 35 years. Six of them had a master's degree in nursing; two had doctoral degree in public health and two were studying doctorate in nursing. The others had specialization in Family Health Strategy, and one of them in neonatology. In relation to previous work, 10 had experience in $\mathrm{PHC}$, for a period varying from two to 34 years, one of whom held the position of professor in nursing technical courses. The other nurses previously worked in the hospital area. As for the current functions, these were diversified, six of which were hired as nursing assistants; six had a dual function, that is, care and management; and four of them were only in the management function or in the coordination of the unit.

\section{Theme 1 - Conceptions and experiences on health promotion}

This theme portrays the meaning attributed by participants to health promotion, based on their conceptions and experiences.

\section{Health promotion is to prevent diseases through health education}

Teaching nurses and PHC nurses strongly related the concept of health promotion with disease prevention.

Health promotion, for me, is to include disease prevention at all. You have to know how to avoid the disease; it is you preventing. (TN1)

Health promotion is to avoid disease, prevent it from manifesting and make a person sick. (N3)

At the same time, when defining health promotion as disease prevention, participants referred to health education, through educational campaigns and campaigns in the waiting room, in clinical consultations, in the work of specific groups and in home visits. 
Health promotion is based on campaigning and working with the population in a way that avoids illness. Campaign for health promotion, educational, that addresses issues of nutrition education, encouragement of physical exercise, going for walks. (TN5)

Educational actions to prevent diseases can be developed in groups, through orientation in the waiting room, during consultations, in home visits. (N6)

\section{Promoting health goes beyond preventing diseases and grievances}

More broadly, some of the participants pointed out that health promotion actions can also permeate actions aimed at lifestyle changes in an autonomous way, seeking better living conditions and health.

Health promotion is all about people's lifestyles and quality of life which includes: no smoking, physical activity, healthy eating, exclusive breastfeeding for children up to six months of age. (TN8)

Promoting health is not waiting for the patient to get sick. It is working empowerment in the care of your own health and coresponsibility with the service. (N2)

\section{It is necessary to know the people as a whole and their social and health needs to promote health}

For both sets of participants in this study, health promotion can only be done if there is recognition of the different dimensions involved in the health-disease process presented by people, focusing on the needs presented.

For me, health promotion is looking at the physiological, spiritual, emotional aspects, seeing the individual as a single being and all the aspects that the individual has; the difficulties. It is trying to heal as much as possible the determinants and risks. (TN4)

I think they have themes that we address and see how it works in relation to health promotion, because it has no ready recipe, like a cake. For example, for us to say, 'Look! You do it like this, like this and that, it works out', we have to see what the population needs, see where we begin to approach. (N13)

\section{Intersectoral and interprofessional work is needed to promote health}

As an essential condition in the development of health promotion actions, due to the breadth and complexity of the factors that may be involved, participants indicated the establishment of intra and intersectoral actions.

So there is the social part that has to work together with health, joining other institutions, in addition to health units. I believe it has to be unified, you know? Teamwork, even, because alone, you will hardly be able to do it. (TN9)

I believe that health promotion can happen at all times when there is health and in any space where there is a health approach, not only in health care institutions, but also in the media, in the various places where life occurs. However, I think it has to be more intrinsic in the work of health professionals who must be more attentive to this. (N15)

\section{Theme 2- Nursing technician's practice in health promotion}

In this theme, subthemes that classify participants' statements about the different aspects favorable to the nursing technician's practice for health promotion in $\mathrm{PHC}$ are related. Also presented are the challenges listed by them for these professionals to overcome the barriers imposed for the accomplishment of this action to the satisfaction.

\section{Nursing technician's work in health promotion benefits from its proximity to the population}

Teaching nurses and those working at PHC, when discussing the work of nursing technicians in health promotion, highlighted the advantage of these professionals to be close to users of health services.

I think the nursing technician, in his practice with the population, makes all the difference, because the population is very needy [...] there is no access and education basis. So, the technician, as a professional who works with the population, has the possibility to actually carry out the education to change the reality, in order to change behavior. (TN8)

The technician has a greater facility of proximity to the population and communicates in a language that often reaches it more effectively. He is a professional who has education that allows advances in the theoretical sense and also a professional who has the practical skills necessary to work in health promotion without resistance [from the population]. (N17)

\section{The nursing technician can develop both individual and collective educational actions}

As an opportunity to carry out health promotion actions, participants pointed out that, in the context of $\mathrm{PHC}$, the nursing technician can develop individual and collective educational actions, including dividing their planning with the nurse or even assuming them, under supervision and properly prepared for this.

I think that the nursing technician is a professional who, when well trained in education or day-to-day at work, is able to participate and even take on both individual and collective activities in health promotion. (N7)

The first step in exercising health promotion effectively is to listen, and here it is always the nursing technician who does this initially. In addition, they have activities that they can have autonomy to be solving, such as knowing how to listen to the patient in a proper and private room and provide some guidelines. Other actions that the nursing technician performs need the nurse's back to solve them, such as participating in patient and family counseling groups. (N10)

However, N15 draws attention not to restrict the role of the nursing technician in specific educational activities of health promotion. 
Health education is fundamental in the work of promoting all professionals, but I am not adept at specific work on the theme "health promotion". I believe that health promotion should be embedded in all approaches, even those considered more technical. I think there is a space to take care of health, which is that of understanding and action that should be as dialogical as possible. I think the prescriptive, normative guidelines are counterproductive without knowing what people think of it. (N15)

\section{The influence of the technicist and biomedical model hinders the work of the nursing technician in health promotion}

Even in view of the potential of nursing technicians to carry out health promotion actions previously portrayed, the technicality that characterizes their practice in PHC was pointed out by participants as a limiting factor to those actions.

Our model focuses on the doctor, on the disease, with a system based on a lot of technique: 'Let's do it and the doctor prescribes it'. (N3)

I think it is necessary to review this concept of limitation of the technician to function only of performing techniques, because as a health professional, he must carry out health promotion actions, provided they are well prepared for it. (TN5)

Nursing technicians should guide both our waiting room and day-to-day groups. In contact with the patient, when performing a procedure, because their activities are not limited to giving medicines, checking blood pressure and collecting exams... (N6)

\section{Lack of organizational conditions, human resources and Permanent Education limit actions to promote health}

As conditions unfavorable to the development of health promotion actions by the nursing technician, participants also point out problems regarding human and organizational resources and the non-achievement of Permanent Education in health units.

I see that some technicians do not have time to talk to the patient. Many people say they do not have the time and end up distancing themselves from patients. More organization and planning is needed [to change this situation]. (TN3)

Sometimes it is difficult for the nursing technician who lives the situation, because it has limitations to carry out educational activities. We, unfortunately, cannot involve the nursing staff at the time of the educational activities, because they are so clear of tasks. (N1)

I believe that he [technician] is able to carry out actions to promote health, but I think that this has to walk in the logic of Permanent Education, working with what appears in the daily work, reflecting on each practice, keeping the logic of action-reflection-action of the team and, also, of the nursing technician. (N15)

\section{Theme 3 - Nursing technician education on health promotion}

Based on their conceptions and experiences in teaching and management and care practice, $\mathrm{PHC}$ professors and nurses discussed the education of nursing technicians, pointing out the aspects to be reviewed in the teaching-learning process on health promotion.

\section{There is little appreciation of education for health promotion}

Regarding the preparation of nursing technicians for health promotion, participants reported that professional education basically has privileged the development of technical procedures. They even pointed out that this education is based on the biomedical model focused on the disease and focused on the hospital performance.

I think that the curriculum with a focus on Primary Care has a much shorter workload, including for the teaching of health promotion. Students arrive at the health clinic knowing practically nothing about it. (TN3)

I understand that the course should start with the subjects of health promotion and have continuity throughout the education, focusing on Public Health, intercalating the stages between BHU, polyclinic, hospital and not only a period in primary care, otherwise, the person will graduate with a hospital head. (N3)

\section{Diseases and their complications prevention and health education are not sufficiently addressed in the education of the nursing technician}

Participants highlighted the insufficiency of the approach in the education of nursing technicians on health education, especially to enable the prevention of diseases and their complications.

\begin{abstract}
Schools need to rethink the education of nursing technicians to value preventive actions, because we see some schools that work a lot the curative part and then it gets very mechanical. I think that the technical education in nursing has to be increasingly focused on the guidelines, because the rich from the nursing in public health is the orientation. If we lose this, we lose our autonomy, ourvalue. (N1)
\end{abstract}

N12 drew attention to the fact that, in the technical teaching in nursing for health promotion, one should not only address disease prevention and health education, but other broader issues, contemplating the problematization of the social determination of the health-disease process.

Well, I think the student needs to have a more global view of the person, for example, when the person arrives at the health unit with hypertension and diabetes. They [health professionals] need not only to see diseases, but to question what that person does, if he works, if he has a child, if he has a job, if he has some type of leisure. You have to have this more global vision, to look at the whole person, not simply the disease and understand that the person needs physical exercise, which needs to have a healthy, leisure food. All this involves something more global. (N12)

TN1 emphasized the importance of developing the ability to adopt an empathic attitude towards health promotion actions.

Teaching should focus on the need to empathize with patients, with individuals, to know how to take care of patients in the spiritual, 
emotional, physiological sense, in the sickness, in their needs. If you put yourself in the other's shoes, I think this is very important when it comes to dealing with health promotion. (TN1)

\section{In the education of nursing technicians for health promo- tion, proactivity and autonomy must be ensured through theoretical-practical integration and the use of active teaching-learning methodologies}

Participants emphasized the importance of integrating theoretical and practical activities and the use of active methodologies as strategies for the meaningful learning of nursing technicians on health promotion, including to generate critical reflection on reality and also to encourage their proactivity.

For health promotion practice, I think we need to deconstruct and rebuild the service and education, because I see that the nursing technician in practice should be prepared to have more professional autonomy to approach health services users, because they come with a gas to work, only that the way they were formed and the work system, their proactivity is inhibited. (N3)

I think it is best to use active methodologies in technical courses, with case discussions in classrooms, putting students in touch with reality, so that they can reflect on it and link practice with theory, with more criticism. (N7)

I have always advocated the logic that teaching must walk along with theory. I believe that the dichotomy between theory and practice undermines the understanding of things. Education must be reflective, with them walking together, enabling reflectionaction-reflection. (N15)

\section{DISCUSSION}

The understanding of the perspective of PHC nurses and teaching nurses on the education and practice of nursing technicians in health promotion, as objectified, allowed identifying and analyzing aspects that contribute to success or impose barriers to the achievement of their premises in the context of PHC.

Initially, it was possible to verify that the teaching nurses and $\mathrm{PHC}$ nurses related, convergently, the concept of health promotion with disease prevention and its complications, pointing out health education as the main strategy to enable actions in this direction at different times and health unit spaces. Still in prevention, participants indicated that in order to promote health, it is necessary to know the people as a whole and their individual health needs.

Thus, it was possible to understand that concepts of disease prevention and health promotion are confused in the understanding of these professionals. However, there are specific definitions for each, and it may be considered that prevention is proposed to avoid diseases, with scientific and prescriptive guidelines of habits changes. Health promotion, in turn, encompasses the idea of self-sufficiency of individuals and collectivities in recognizing and dealing with the different determinants and conditions of the health-disease process, in order to produce health and better quality of life $\mathrm{e}^{(4)}$. It is worth emphasizing that the conception of health education linked only to the concept of disease prevention implies limiting educational actions to normative orientations aimed at behavioral changes. And even with the aim of educating people to acquire healthy habits, these types of actions often consider individuals as passive subjects who, when they present health problems or do not change their behavior, are blamed for not having followed what was guided by health professionals ${ }^{(15)}$.

Among the participants' conceptions about health promotion, those that, in addition to education for disease prevention, have emerged in the sense of incorporating actions to ensure co-responsibility for the production of health by professionals and their users, with a view to changing life and health habits, autonomously and in line with social needs.

It is believed that, to a certain extent, conceptions on health promotion of participants have been following up the changes of their conceptions on the health-disease process, when it is begun to recognize, in an extended way, both biological aspects and social, cultural and economic aspects involved in its determination, as contemplated in the Brazilian Federal Constitution of 1988, the Brazilian Organic Law on Health (Lei Orgânica) 8080/1990 and other official documents ${ }^{(16)}$. In this new way of thinking health promotion includes the valuing of the own choices of individuals and communities on their health, in a conscious and autonomous way, according to their needs and potentialities, which are permeated by empirical knowledge, and shared with professional knowledge ${ }^{(17)}$.

Still at conception level and guided by the considerable challenge to enable health promotion actions, participants indicated the necessary sharing of responsibility for these actions, with professionals from other levels of health care and with other sectors of society, but drawing attention to the role of the health sector in these actions.

Consistent with the guidelines of SUS, in the theoretical area, the greatest chance of solving problems and work in health promotion is recognized, when communication within and outside the health sector is established, in order to contemplate the multiple aspects that involve life in different social contexts. Nonetheless, in the reality of services, intersectorality is considered as complex, little discussed and restricted to workers with higher education ${ }^{(18)}$.

Contrary to the Brazilian and international political propositions, the literature presents precise diagnoses as to how to promote health and the existence of manuals and materials that are good enough in relation to the subject, in the context of professional practices, many disparities and gaps still exist, as reported by participants. Therefore, when referring to the nursing technician practice in health promotion, they pointed out the different possibilities of this professional working with the health team, at the same time, punctuating the challenges to overcome the barriers imposed for the effectiveness of this action.

Maintaining convergence with their conceptions about health promotion, previously discussed, the two sets of nurses stressed the importance of establishing close relationships to meet them, when recognizing health and social needs. In this sense, they highlighted the potential of nursing technicians to perform qualified listening of the needs and demands of the people, during the care provided to them, for the achievement of health education.

There were several references on the importance of qualified listening associated with the possibilities of health promotion. However, there was a great emphasis on the technicist practice 
of nursing technicians at $\mathrm{PHC}$, which distances them from the possibilities of dialoguing with the users served by them. Qualified listening creates the possibility of offering care that goes beyond the limits of scheduled, programmatic demands, enabling equitable, interdisciplinary and intersectoral interventions and contributing to the change of the health work process ${ }^{(19)}$.

Nurses should sensitize nursing teams regarding the importance of education and health promotion, so that all nursing technicians act, both in the technical and educational part, thus avoiding conflicts between professionals who consider the educational work of minor value than the technician.

Participants also pointed as limiting factors for health promotion actions by nursing technicians: the lack of organizational, human resources and Permanent Education conditions. Permanent health education is considered to be a pertinent strategy within the governance of health unit professionals to bring about changes in the work process in PHC, involving the whole team actively to identify problems, seek possible solutions and reorganize their practices ${ }^{(20)}$, as opposed to the biomedical and disease-centered hegemonic care model ${ }^{(16)}$.

In addition to acting in individual care, another opportunity for nursing technicians to act in relation to health promotion in the context of PHC indicated by participants was their effective participation in the work of educational groups and preventive campaigns, mainly within the health units, although some PHC nurses called attention to not be restricted the role of the nursing technician the health promotion, only to these specific activities. Thus, a restricted view on the potential of health promotion through collective actions is revealed, considering that participants did not consider actions aimed at the creation of environment favorable to health and encouragement of community participation, pointed out from the first official publications on the subject ${ }^{(3)}$.

Based on their conceptions and experiences in teaching and managerial and care practice in $\mathrm{PHC}$, participants discussed the education of nursing technicians, pointing out the aspects to be reviewed in the teaching-learning process on health promotion.

In this sense, they recognized that technical education in nursing has not enabled the necessary education for health promotion by its students, being basically prepared to perform technical procedures. In this context, it can be seen that some education institutions are more committed to vocational and marketing education than to an integrated, critical and reflexive education ${ }^{(21)}$.

Participants pointed out as an important approach in the education of the nursing technician, the social determination of the health-disease process model, combining the development of attitudes as empathic attitude towards health services users, as well as using strategies to generate proactivity and autonomy of the health-disease process and health promotion. For this, it was indicated the adoption of active methodologies and theoretical-practical integration as significant strategies for the achievement of these objectives. Finally, although mentioned by only one participant, it was pointed out the importance of professor education in the subject and the best ways to approach it in nursing technical courses.

Active methodologies adoption has been proposed in the field of health at several levels, including health education. There is interest and need to solve problems and build new knowledge, based on previous experiences, especially to provide instruments to learn how to overcome health challenges, especially in PHC. In this sense, the formative potentiality of the active methodology constitutes an important teaching-learning strategy of the health professional, based on the expectation of a marked autonomy. This is in line with what is expected of these professionals, that is, they are able to solve problems by means of an overall analysis of the context of each case, and not only performing techniques without the need for reflection ${ }^{(22)}$.

Shortcomings in nursing technical education regarding health promotion, according to participants, also derive from the dichotomy between theory and practice, therefore, making it necessary to review the articulation between them.

Currently, educational institutions must rethink the education guidelines, seeking the development of competences, skills and attitudes to start professional activities, in order to match the demands of the labor market, the specificities of the profession, as well as the needs and individual and collective health demands. Articulation between theory and practice should be seen as a unique factor in this development, and the practical training should be alternated with theoretical training, because it is in practice that professional learning happens ${ }^{(1)}$, being in the reflection-action-reflection that practice becomes significant for professionals ${ }^{(10)}$, with better chances of success.

\section{Study limitations}

Although the contributions of teaching nurses and those working in $\mathrm{PHC}$ have been configured in important evidences about the education and practice of nursing technicians in health promotion, this study has the limitation not to contemplate the perspective of the latter, both those in formation, and those who were already working in health units on the focused subject. It is believed that the presentation and confrontation of different ways of thinking and diverse experiences could contribute more to better vocational training, with positive consequences for the desired practice.

\section{Contributions to Nursing}

This study contributes to the advancement of knowledge about aspects related to the nursing technicians' education, presenting scientific evidences to give a new meaning to the participation of these professionals in actions of health promotion in the context of PHC and for the reorganization of the teaching-learning process, in order to carry them out successfully.

\section{FINAL CONSIDERATIONS}

As an objective, from the perspective of teaching nurses and those working in $\mathrm{PHC}$, an analysis was made on the education and practice of nursing technicians in health promotion. This analysis showed that there is a need to broaden the approach to health promotion in the education courses for nursing technicians, so that they are able to contribute to actions aimed at health promotion, which have proved to be little or not performed in practice of these professionals. 
Nursing technicians' education approach is important as well as the expanded concept of the health-disease process, the model of the social determination of this process, education in emancipatory health and the current premises of health promotion, especially punctuating their distinctions in relation to prevention of diseases and grievances.

Furthermore, professional education through active methodologies and theoretical and practical integration, not only the development of technical and scientific skills to perform diagnostic and curative procedures prescribed by other members of health teams are unquestionably fundamental. It is also fundamental to develop attitudes, such as qualified listening, empathy, solidarity, autonomy and proactivity, focused on interdisciplinarity, intersectoriality, social participation, articulation and dialogue between professionals and between professionals, and the people to be cared for and the community.

\section{REFERENCES}

1. Oviedo RAM, Czeresnia D. O conceito de vulnerabilidade e seu caráter biossocial. Interface [Internet]. 2015 [cited 2018 Sep 10];19(53):23749.Available from: https://www.scielosp.org/pdf/icse/2015.v19n53/251-264/pt

2. Tavares MFL, Rocha RM, Bittar CML, Petersen CB, Andrade M. Health promotion in professional education: challenges in Health and the need to achieve in other sectors. Ciênc Saúde Coletiva [Internet]. 2016 [cited 2018 Jun 17];21(6):1799-808. Available from: http://www. scielo.br/pdf/csc/v21n6/en_1413-8123-csc-21-06-1799.pdf

3. Ministério da Saúde (BR). Secretaria de Vigilância em Saúde. Secretaria de Atenção à Saúde. Política Nacional de Promoção da Saúde: PNPS: revisão da Portaria MS/GM n687, de 30 de março de 2006. Brasília: Ministério da Saúde [Internet] 2015 [cited 2017 Apr 30]. Available from: http://bvsms.saude.gov.br/bvs/publicacoes/pnps_revisao_portaria_687.pdf

4. Berlt M, Abaid, JLW. Educação e autonomia na autopromoção da saúde bucal de gestantes. Disciplinarum Scientia [Internet]. 2017 [cited 2018 Jan 06];18(1):169-81. Available from: https://www.periodicos.unifra.br/index.php/disciplinarumS/article/view/2260/2024

5. Conselho Federal de Enfermagem. Enfermagem em números. Brasília (DF): CFE [Internet]. 2018 [cited 2018 Jun 21] Available from: http:// www.cofen.gov.br/enfermagem-em-numeros

6. Salvador PT, Vítor AL, Ferreira Jr MA, Fernandes MI, Santos VE. Systematization of teaching nursing care at a technical level: perception of professors. Acta Paul Enferm [Internet]. 2016[cited 2018 Jun 21];29(5):525-33. Available from: http://www.scielo.br/pdf/ape/v29n5/en_19820194-ape-29-05-0525.pdf

7. Ministério da Educação (BR). Resolução n 6, de 20 de setembro de 2012. Dispõe sobre as Diretrizes Curriculares Nacionais para a educação profissional técnica de nível médio. Diário Oficial da União. 21 set 2012

8. Quadros JS, Colomé JS. Metodologias de ensino-aprendizagem na formação do enfermeiro. Rev Baiana Enferm [Internet]. 2016 [cited 2018 Jan 06];30(2):1-10. Available from: https://portalseer.ufba.br/index.php/enfermagem/article/viewFile/15662/pdf_43

9. Marin MJS, Tonhom SFR, Michelone APC, Higa EFR, Bernardo MCM, Tavares CMM. Projections and expectations of students enrolled in a teaching qualification in a technical health professional education course. Rev Esc Enferm USP [Internet]. 2013[cited 2018 Jan 06];47(1):21724. Available from: http://www.scielo.br/pdf/reeusp/v47n1/en_a28v47n1.pdf

10. Souza KR, Rodrigues MAS, Fernandez VS, Bonfatti RJ. A categoria saúde na perspectiva da saúde do trabalhador: ensaio sobre interações, resistências e práxis. Saúde Debate [Internet]. 2017 [cited 2018 Jan 06];41 (Esp.):254-63.Available from: http://www.scielo.br/pdf/sdeb/ v41nspe2/0103-1104-sdeb-41-spe2-0254.pdf

11. Conselho Nacional de Saúde (BR). Resolução n. 466 de 12 de dezembro de 2012. [Internet] 2012 [cited 2018 Jun 21]. Available from: http:// conselho.saude.gov.br/resolucoes/2012/reso466.pdf

12. Minayo MCS. Sampling and saturation in qualitative research: consensuses and controversies. Rev Pesq Qualit[Internet]. 2017 [cited 2018 Jun 15];5(7):1-12. Available from:http://rpq.revista.sepq.org.br/index.php/rpq/article/view/82/59

13. Tong A, Sainsbury P, Craig J. Consolidated criteria for reporting qualitative research (COREQ): a 32-item checklist for interviews and focus groups. Int J Qual Health Care [Internet]. 2007 [cited 2018 Sep 10];19(6):349-57. Available from: https://academic.oup.com/intqhc/ article/19/6/349/1791966

14. Minayo MC. O desafio do conhecimento: pesquisa qualitativa em saúde. São Paulo: Hucitec; 2014.

15. Sasaki AK, Ribeiro MPDS. Percepção e prática da promoção da saúde na estratégia saúde da família em um centro de saúde em São Paulo, Brasil. Rev Bras Med Fam Comunidade [Internet]. 2013 [cited 2018 Jun 15];8(28):155-63. Available from: https://www.rbmfc.org.br/rbmfc/ article/view/rbmfc8\%2828\%29664/568

16. Ceballos AGC. Modelos conceituais de saúde, determinação social do processo saúde e doença, promoção da saúde. Recife: UNA-SUS UFPE [Internet]. 2015 [cited 2018 Jun 11];1-22. Available from: https://ares.unasus.gov.br/acervo/handle/ARES/3332?show=full

17. Reis INC, Silva ILR, Un JAW. Espaço público na Atenção Básica de Saúde: Educação Popular e promoção da saúde nos Centros de SaúdeEscola do Brasil. Interface [Internet]. 2014 [cited 2018 Jun 12];18(Supl 2):1161-74. Available from: http://www.scielo.br/pdf/icse/v18s2/18075762-icse-18-s2-1161.pdf

18. Cavalcanti AD, Cordeiro JC. Conceito de saúde e ações intersetoriais na Estratégia de Saúde da Família. Rev Bras Med Fam Comunidade [Internet]. 2015 [cited 2018 Jun 12];10(37):1-9. Available from: https://www.rbmfc.org.br/rbmfc/article/view/1059 
19. Duarte LPA, Moreira DJ, Duarte EB, Feitosa ANC, Oliveira AM. Contribuição da escuta qualificada para a integralidade na atenção primária. Rev Eletr Gestão Saúde [Internet]. 2017 [cited 2018 Jun 12];8(3):414-29. Available from: http://periodicos.unb.br/index.php/rgs/article/ view/24185/pdf

20. Firmino V, Amestoy SC, Santos BP, Casarin ST. Family Health Strategy: nursing care management. Rev Eletr Enf [Internet]. 2017 [cited 2018 Apr 19];19:a05. Available from: https://www.revistas.ufg.br/fen/article/view/42691/22859

21. Ramos J, Costa MA. Formação profissional dos técnicos em enfermagem frente a reforma do ensino médio: tecnicista ou politécnica? IV Colóquio Nacional e I Colóquio Internacional: aprodução do conhecimento em educação profissional [Internet]. 2017[cited2018 Apr 19]. Available from: https://ead.ifrn.edu.br/coloquio/anais/2017/trabalhos/eixo1/E1A35.pdf

22. Paiva MRF, Parente JRF, Brandão IR, Queiroz AHB. Metodologias ativas de ensino aprendizagem: revisão integrativa. SANARE [Internet]. 2016[cited 2018 Jun 12];15(2):145-53. Available from: https://sanare.emnuvens.com.br/sanare/article/view/1049/595 